Jurnal Konstruksi Hukum | ISSN: 2746-5055

Vol. 2, No. 2, Mei 2021, Hal. 296-302| Tersedia online di

https://www.ejournal.warmadewa.ac.id/index.php/jukonhum

DOI: https://doi.org/10.22225/jkh.2.2.3226.296-302

\title{
AKIBAT HUKUM TERHADAP PELAKSANAAN ARISAN ONLINE BERDASARKAN UNDANG- UNDANG NOMOR 19 TAHUN 2016
}

\author{
Erlin Kusnia Dewi, Anak Agung Sagung Laksmi Dewi, I Made Minggu Widyantara \\ Fakultas Ilmu Hukum Universitas Warmadewa \\ erlinkusniadewi@gmail.com, laksmidewi29@gmail.com \& mademinggu@gmail.com
}

\begin{abstract}
Abstrak
Diera modern saat ini tentunya banyak kemudahan-kemudahan yang disajikan oleh internet, salah satunya adalah arisan online. Arisan online adalah kegiatan mengumpulkan dana dalam satu kelompok yang menggunakan sistem undi untuk memperolehnya tapi secara online atau tanpa bertatap muka. Selanjutnya, UU ITE tahun 2008 mengatur tentang tindakan penipuan yang diterapkan secara daring. Peneliti menulis sebuah artikel ilmiah yang memiliki judul Akibat Hukum Hukum Terhadap Pelaksanaan Arisan online. Berdasarkan UU No 19 Tahun 2016. Penelitian ini bertujuan untuk mengetahui hukum yang dapat memayungi para pelaku arisan online. Terdapat dua rumusan masalah dalam penelitian ini yaitu Bagaimana Perlindungan Hukum Bagi para pihak yang melaksanakan arisan online berdasarkan Undang-undang Nomor 19 Tahun 2016 dan bagaimana sanksi pidana terhadap bandar arisan online jika terjadi wanprestasi. Penelitian hukum Normatif merupakan metode yang diterapkan oleh peneliti dalam artikel ilmiah ini. Peneliti menggunakan pendekatan konseptual dan pendekatan perundang-undangan dalam membahas permasalahan penelitian Peneliti melaksanakan studi kepustakaan dengan mengumpulkan bahan hukum untuk menjawab rumusan masalah penelitian. Penemuan dalam studi ini menjelaskan bahwa terdapat perlindungan hukum bagi para pihak yang melakukan arisan online dan Sanksi pidana terhadap bandar arisan daring berdasarkan UU ITE No 19 Tahun 2016 terhadap pelaku penipuan arisan daring berfokus terhadap subjek hukum individual. Penemuan ini didukung dengan Pasal 28 ayat (1) yang menjelaskan bahwa konsumen yang memperoleh kerugian karena melakukan transaksi secara daring memiliki kesempatan untuk memperoleh perlindungan hukum.
\end{abstract}

Kata Kunci: Arisan online, Penipuan, Sanksi pidana, UUITE.

\begin{abstract}
The 2008 ITE Law regulates fraudulent acts that are applied online. The researcher wrote a scientific article with the title Legal Impacts on the Implementation of Online Arisan Based on Law No. 19 of 2016. There are two formulations of this research problem How is the Legal Protection for Parties Conducting Online Arisan based on Law Number 19 of 2016? and What are the Criminal Sanctions Against BandarArisanOnlinein the event of Default? Normative legal research is a method applied by the author in this scientific article. The author carries out a literature study by collecting legal material to answer the formulation of research problems. The author carries out a literature study by collecting legal material to answer the formulation of research problems. This study's findings explain that there are legal protections for parties who carry out online social gathering criminal sanctions against online social gathering based on ITE Law No. 19 of 2016 against online social gathering fraud perpetrators focused on individual legal subjects. This finding is supported by Article 28 paragraph (1), which explains that consumers who get losses due to online transactions can obtain legal protection.
\end{abstract}

Keyword: Online Social Gathering, Criminal Sanctions, Fraud, UUITE

\section{PENDAHULUAN}

Bagi umat manusia saat ini terdapat banyak kemudahan yang diberikan oleh perkembangan teknologi tanpa Batasan waktu untuk melakukan interaksi antar sesame manusia merupakan kemudahan yang ditawarkan oleh kemajuan ilmu pengetahuan dan teknologi. Internet memberikan kemudahan bagi seseorang untuk menikmati dunia maya (virtual reality) sehingga menggantikan peran komunikasi konvensional berdasarkan proses globalisasi yang berkembang pesat. Dalam perkembangan ini terdapat pelaku yang ingin memanfaatkan dengan cara mencari keuntungan dari dirinya sendiri dengan melakukan berbagai cara demi mencapai yang si pelaku inginkan (Mertokusumo, 2014). 
Internet menawarkan berbagai hal yang dapat dimanfaatkan oleh manusia, yakni melakukan kegiatan sosialita, menjalankan bisnis secara online, bekerja dan berhubungan sosial. Sebuah kegiatan jual-beli maupun investasi merupakan aktivitas yang dapat dilakukan melalui bisnis online. Namun terdapat aktivitas populer yang dilakukan oleh masyarakat Indonesia saat ini yaitu arisan berbasis online, sebuah wadah untuk melaksanakan kegiatan sosial. Pelaksanaan arisan tidak lagi menggunakan prinsip konvensional, melainkan juga telah berkembang menggunakan sistem daring baik melalui software (Hariyanto,et.al 2018). Arisan merupakan sebuah kegiatan dalam mengumpulkan sebuah dana atau barang yang memiliki nilai di mata masyarakat dan jumlah dari yang diperoleh akan diberikan pada seseorang yang beruntung berdasarkan undian. Kalangan usia muda merniliki ketertarikan yang sangat tinggi terhadap arisan online karena mempermudahkan kegiatan lainnya. Kemudahan itu terjadi karena hanya dengan menggunakan media sosial, namun anggota arisan online dapat melakukan interaksi sesama manusia dan melakukan transaksi tanpa harus bertemu tatap muka secara langsung (Riawan \& Mahartayasa 2015). Dengan adanya sistem daring, praktik arisan lebih mudah dilakukan dengan jangkauan yang lebih luas (Ramadhita \& Khoiriyah, 2018).

Di Indonesia, arisan merupakan fenomena sosial yang terjadi diberbagai daerah (Masithah, 2018). Di masa lampau, masyarakat hanya bisa mengadakan kegiatan arisan melalui tatap muka secara langsung. Namun melalui media sosial dan peningkatan jaringan internet yang semakin luas, arisan ini dapat diadakan secara daring berdasarkan inisiatif pengguna dunia maya yang semakin meningkat dan semakin pesatnya perkembangan teknologi. Arisan online merupakan pemanfaatan media sosial yang terhubung dengan jaringan internet untuk mengadakan arisan tanpa bertemu secara langsung. Terdapat bandar atau pengelola arisan sehingga kegiatan ini dapat diadakan tanpa tatap muka para anggotanya. Para anggota dapat memanfaatkan fasilitas transfer yang terdapat dalam Automated Teller Machine (ATM) atau m-banking untuk melakukan transaksi pembayaran uang arisan. Cara melakukannya yaitu, anggota arisan online mernilih nomor urut dan membayar iuran yang telah ditentukan oleh Bandar dan setelah jangka wakru yang ditentukan anggota arisan pun mendapatkan haknya. Sebuah sikap saling percaya merupakan hal yang sangat dibutuhkan dalam melaksanakan kegiatan online.

KUHPerdata mengatur secara berbeda tentang perjanjian dalam konsep arisan. Dalam hal ini, perjanjian bernama merupakan sebuah ikatan perjanjian yang memiliki karakter khusus dan diatur dalam norma hukum dan asas hukum yang dapat ditemui pada Bab II hingga Bab XVIII pada buku Ill KUHPerdata. Prestasi yang berkaitan dengan perjanjian adalah sebuah penerapan yang dilakukan oleh kedua belah pihak untuk mengikatkan diri terhadap berbagai hal yang telah disepakati sesuai dengan yang telah tertulis di dalamnya atas suatu perjanjian.

Wanprestasi atau ingkar janji merupakan lawan kata atau perbedaan dari kata prestasi. Wanprestasi dapat menimbulkan kerugian pada pihak lain karena suaru pihak tidak melaksanakan kewajiban, janji-janji, atau prestasi sesuai dengan yang tertulis di perjanjian terhadap pihak-pihak tertentu dalam perjanjian terdapat kesulitan untuk mengungkap kasus penipuan arisan online karena memiliki sistem pembuktian yang lemah. Kasus penipuan online yang meningkat karena lemahnya pengaturan yang mengatur hal ini. Hal ini juga berkaitan dengan berbagai situs-situs yang memiliki indikasi penipuan masih belum mampu untuk dilacak oleh pemerintah. Sehingga sangat sulit untuk dilakukan upaya untuk menurunkan kasus penipuan arisan online. Pencarian alat bukti merupakan kesulitan yang biasanya dialami oleh pihak kepolisian. Pihak yang sangat ahli di bidang IT merupakan kebutuhan untuk memperoleh bukti dalam kasus menggunakan media sosial ini. Pada hakikatnya masyarakat tidak dapat secara sernena-mena untuk memanfaatkan teknologi karena sudah diatur dalam peraturan yang disusun oleh pemerintah yaitu UU No 19 Tahun 2016 atas perubahan UU No 11 Tahun 2008 tentang ITE. Di lain pihak, banyak pihak yang menganggap belum maksimalnya penerapan Undang-Undang tersebut. Hal ini terjadi karena peraturan yang terdapat dalam UU ITE masih belum jelas mengatur tindak pidana cybercrime. Olehkarenanya, Penelitian ini bertujuan untuk mengetahui hukum yang dapat memayungi para pelaku arisan online dan peneliti telah merumuskan masalah penelitian menurut uraian di aras, yairu Bagaimanakah Perlindungan Hukum bagi Para Pihak yang Melaksanakan Arisan Online berdasarkan UU No. 19 Tahun 2016 serta Bagaimanakah Sanksi Pidana terhadap Bandar Arisan Online jika terjadi Wanprestasi. 


\section{METODE PENELITIAN}

Penelitian hukum yuridis merupakan pendekatan masalah dan tipe penelitian yang dilakukan oleh peneliti unruk rnemecahkan rumusan permasalahan di atas. Peneliti menerapkan sebuah penelitian yang memanfaatkan berbagai studi empiris untuk memperoleh teori-teori tentang tahapan terjadi dan bekerjanya hukum yang terdapat pada masyarakat. Tidak hanya itu, riset empiris dapat digunakan buat mengamati hasil dari tingkah laku manusia berupa peninggalan aset raga ataupun arsip (Fajar \& Achmad, 2015). Untuk memperoleh kebenaran obyektif, peneliti menggunakan penalaran induktif dan deduktif melalui pendekatan konseprual dan pendekatan perundang-undangan dalam membahas permasalahan penelitian. Penelitian ini menggunakan sumber bahan hukum primer sebagai data penelitian. Sehingga peneliti memanfaatkan berbagai perangkat hukum atau peraturan perundangundangan sebagai sumber data primer. Sedangkan penelitian ini memanfaatkan hasil penelitian terdahulu, pendapat ahli, laporan-laporan, karya ilmiah, dan buku-buku sebagai bahan hukum sekunder. Penelitian ini bersifat deskriptif analitik yaitu penelitian yang bertujuan untuk menggambarkan dan menganalisa mengenai subjek yang diteliti dalam fakta yang sebenarnya dan tidak dimaksudkan untuk menguji hipotesis (Ali, 2014).

Peneliti memanfaatkan instrumen pengumpulan data penelitian melalui studi kepustakaan atau studi dokumen sebagai teknik memperoleh bahan hukum penelitian. Setiap peraturan perundangundangan yang memiliki kaitan hukum perjanjian merupakan bahan hukum primer dalam teknik srudi dokumen yang dilakukan peneliti. Sedangkan KUHPerdata dimanfaatkan untuk membanru peneliti dalam menganalisis hukum atas munculnya wanprestasi terhadap suatu perjanjian.

\section{HASIL DAN PEMBAHASAN}

\section{Perlindungan Hukum Terhadap Pelaksanaan Arisan Online}

Berdasarkan Undang-Undang Nomor 19 Tahun 2016 Terdapat perbedaan satu dengan lainnya terhadap praktik dan kebiasaan dalam menyelenggarakan arisan berdasarkan perkembangan globalisasi saat ini. Penggunaan cara undian merupakan cara pengelola untuk menentukan siapa yang akan memperoleh dana arisan setiap minggu dan memanfaatkan media sosial untuk menjalin komunikasi antara sesama anggota arisan. Arisan online merupakan arisan yang berbasis online yang memiliki banyak peminat karena dapat memudahkan setiap orang dengan melakukan arisan tanpa tatap muka. Terdapat beberapa jenis arisan dalam masyarakat yaitu arisan uang dan arisan barang, yaitu

1) Arisan uang, arisan ini banyak dilakukan oleh masyarakat umum yang harus diundi terlebih dahulu untuk mengetahui anggota yang memiliki hak untuk memperoleh dana yang telah dihimpun. Terdapat beberapa jenis arisan ini, seperti

a) Arisan biasa, yaitu sebuah arisan yang memiliki kesepakatan bahwa yang memperoleh dana terakhir memberikan pinjaman tanpa bunga sedangkan seseorang yang memperoleh dana awal akan memperoleh pinjaman tanpa bunga.

b) Arisan tembak, yaitu arisan lelang. Anggota yang sedang membutuhkan dana dapat meminta kepada kelompok agar memperoleh dana arisan sesuai kesepakatan. Sedangkan anggota yang memiliki masalah dan tidak membayar akan didanai oleh pemenang pertama. Pemenang awal juga memiliki tanggung jawab untuk menghimpun dana arisan atas mandat dari ketua kelompok.

c) Arisan sistem gugur, yaitu seorang anggota tidak memi liki kewajiban untuk membayar dana arisan karena ia telah selesai mengikuti kegiatan berdasarkan perjanjian dan ketentuan dalam jangka waktu tertentu.

d) Arisan sistem menurun, yaitu terdapat perbedaan jumlah dana yang dihimpun oleh setiap anggota kelompok.

e) Arisan daring, yaitu arisan yang dilaksanakan secara daring dan berisiko tinggi karena tidak adanya perjanjian secara tertulis dan dapat terjadi wanprestasi.

Arisan Barang, yaitu sebuah penghimpunan dana yang ditujukan untuk membeli suatu barang dan diberikan pada anggota pemenang undian arisan. Berbagai alat rumah tangga dan barang kebutuhan pokok merupakan contoh dari arisan barang (Kusuma, 1990).

a) Bandar arisan, yaitu pihak pemegang arisan yang berperan penting dalam menghimpun dana arisan dan mengelola jalannya suatu arisan dalam sebuah perikatan.

b) Peserta arisan, yaitu pihak yang mengikuti atau yang telah terikat dalam sebuah perjanjian dalam pelaksanaan arisan. 
c) Media sosial, yaitu sebuah media untuk bersosialisasi saru dengan yang lainnya tanpa batasan waktu

d) Bank, yaitu pihak penyimpanan dana dan penyalur transaksi yang dilakukan oleh peserta arisan online dan Bandar arisan online tanpa bertemu.

Dengan berkembangnya dunia teknologi, arisan dapat dilakukan secara online yang mampu memberikan manfaat dalam pelaksanaannya, yaitu rneningkatkan rasa kesetiakawanan dengan saling percaya sesama anggota, sebuah wadah untuk melatih kemampuan menabung uang, memperluas pertemanan dengan bersosialisasi, mendapatkan uang yang nilainya jelas, dan dapat digunakan sebagai sarana promosi. Namun keunggulan utama dari arisan online adalah peserta dapat memperoleh pinjaman tanpa bunga jika mendapat nomor urut paling aw al. Dalam hal ini peran dari pemerintah untuk menanggulangi dampak negatif yang ditimbulkan sangat dibutuhkan (Ali, 2002: 64).

Terdapat beberapa kendala dalam melaksanakan perjanjian yang terdapat dalam arisan online, yaitu

a) Permasalahan khusus yaitu keterlambatan pembayaran dana arisan. Sehingga bandar arisan harus menutupi iuran anggota yang mengalami keterlambatan pembayaran yang terjadi akibat berbagai alasan tertentu.

b) Permasalahan umum, yaitu untuk menyelesaikan permasalahan pembayaran harus ada unsur kepercayaan antara sesama anggota sehingga peserta dan bandar arisan harus memiliki pola pikir untuk membayar iuran tepat waktu. Hal ini dilakukan unruk menghindari kerugian banyak pihak.

Terdapat sisi negatif dan positif dalam mengembangkan arisan online berdasarkan berbagai fakta yang ada. Setiap anggota memperoleh keuntungan dengan mendapatkan pemasukan keuangan, belajar untuk menabung, dan rneningkatkan hubungan pertemanan rnerupakan manfaat positif dalam rnelaksanakan arisan online. Sedangkan terdapat anggota arisan yang tidak melaksanakan tanggung jawab pembayaran merupakan persoalan utama dari keamanan dan transaksi yang merupakan dampak negatif kegiatan ini tiidak mewajibkan perjanjian dalam berbentuk tertulis diatur dalam ketentuan Pasal 1320 KUHPerdata yang merupakan suatu bentuk perlindungan hukum yang dimiliki oleh peserta arisan online . Para peserta memiliki hak dan kewajiban unruk memiliki kepercayaan dalam menjaga perjanjian lisan yang terdapat dalam arisan online. Perjanjian ialah sebuah hubungan hukum antara kedua pihak atau lebih untuk melaksanakan suatu hal berdasarkan kesepakatan yang telah disetujui (Khairandy, 2013). Asas Konsensualisme merupakan asas yang sangat mendasar dalam perjanjian karena kesepakatan, merupakan dasar terjadinya sebuah perjanjian antara kedua belah pihak. Untuk terciptanya kepastian hukum, dibutuhkan asas konsensualisme sebagai syarat mutlak bagi hukum perjanjian (Subekti, 2006).

Pelaku penipuan online hanya dapat dikenakan sanksi pidana berdasarkan Pasal 45 ayat (2) Undang-Undang Nomor 19 Tahun 2016 tentang informasi Transaksi Elektronik. Sedangkan untuk mempertanggungjawabkan perbuatannya, pelaku tindak pidana penipuan online tidak dapat dibebani untuk memperoleh hukuman berdasarkan Pasal 378 KUHP. Hal ini terjadi karena pelaku tersebut memiliki beberapa hambatan untuk diberikan sanksi pidana. Kegiatan arisan online merupakan sebuah transaksi elektronik yang dapat merugikan konsumen seperti tindak pidana penipuan. Namun hal ini tidak khusus diatur dalam UU ITE. Sehingga pelaku dapat diberikan sanksi yang terdapat dalam Pasal 45A ayat (I) dan Pasal 28 ayat (I) UU No 19Tahun 2016 perubahan atas UU No 11 Tahun 2008 tentang fTE atau tindak pidana penipuan dan penggelapan yang terdapat dalam Pasal 378 KUHP dan Pasal 372 KUHP dan/atau Pasal 3, 4 UU No 8 Tahun 20 IO ten tang pencegahan pemberantasan tindak pidana pencucian uang dan Pasal 55 ayat (I) ke-Ie KUHP. Dengan adanya UU No 19 Tahun 2016 tentang lnformasi dan Transaksi Elektronik, pelaku tindak pidana penipuan online dapat mempertanggungjawabkan perbuatannya sehingga dapat memberikan sanksi pelaku, meskipun tidak secara khusus menjelaskan peraturan tindak pidana penipuan.

\section{Sanksi Pidana Terhadap Bandar Arisan Online Jika Terjadi Wanprestasi}

Wanprestasi dalam arisan muncul jika terdapat pihak yang memiliki kaitan dengan arisan lari dari tanggung jawab yang telah disepakati sebelumnya. Contoh yang umum terjadi adalah segelintir orang yang tidak membayar iuran arisan dan menghilang karena sudah memperoleh dana arisan yang dikumpulkan. Setiap anggota yang telah melakukan suatu perjanjian wajib untuk melaksanakan 
kewajiban untuk rnembayar iuran sesuai dengan ketentuan yang telah disepakati, Sehingga tidak rnenyelesaikan iuran secara lancar merupakan tindakan wanprestasi yang umum ditemui pada kegiatan arisan online. Bandar arisan online merupakan pihak yang paling bertanggung jawab untuk membayar iuran yang seharusnya dilaksanakan oleh peserta arisan yang tidak melaksanakan tugasnya. Sehingga pihak yang tidak bertanggung jawab tersebut secara sengaja melakukan kelalaian dalam tindakan wanprestasi ini.

Wanprestasi merupakan tindakan untuk rnengganti bunga, kerugian, atau biaya karena seseorang tidak memenuhi kewajibannya berdasarkan waktu yang telah ditentukan berdasarkan Pasal 1243 KUHPerdata. Setiap hukum pidana merniliki unsur penting yaitu pertanggungjawaban pidana. Setiap Undang-Undang akan mengatur secara merata tindak pidana, sehingga hal tersebut tidak hanya terdapat dalam KUHP. Undang-Undang Nomor 19 Tahun 2016 tentang lnformasi dan Transaksi Elektronik (UU ITE) dan KUHP yang mengatur peraturan dan sanksi hukum bagi pelanggaran yang terjadi karena arisan daring.

Pengertian perjanjian hanya diberikan Batasan secara umum dalam Undang-Undang Informasi dan Transaksi Elektronik. Perjanjian menurut Pasal 1 angka 17 UU ITE menjelaskan bahwa sistem elektronik dapat dimanfaatkan dalam melakukan perjanjian oleh berbagai pihak yang membutuhkan. Di lain pihak, Sistem Elektronik yang dimaksud adalah sekumpulan prosedur dan perangkat elektronik yang memiliki fungsi untuk menyebarkan, mengirimkan, mengumumkan, menampilkan, menyimpan, rnenganalisis, mengolah, dan mengumpulkan informasi elektronik. Informasi elektronik yang terdapat dalam kalimat diatas adalah suatu atau kumpulan data elektronik yang tidak terbatas pada simbol, perforasi, kode akses, tanda, huruf, angka, telecopy atau sejenisnya, telegram, teleks, Electronic Data Interchange (EDI), Surat Elektronik (E-mail), rancangan, tulisan, peta, foto, gambar, dan suara yang telah diolah dan memiliki arti dan dapat dimengerti oleh seseorang yang dapat mengerti.

Keabsahan kontrak atau perjanjian elektronik hanya dijelaskan secara singkat pada UU ITE. Sedangkan setiap pihak memiliki keterikatan dengan Kontrak Elektronik yang dibuat berdasarkan Transaksi Elektronik yang dilakukan berdasarkan Pasal 18 ayat (1) UU ITE. Sehingga para pihak yang melaksanakan perjanjian terikat dengan kontrak atau perjanjian elektronik berdasarkan rumusan dan analisa pasal tersebut. Suatu perjanjian akan dikatakan memperoleh perlinduangan hukum jika syarat sah yang ditenrukan telah dipenuhi berdasarkan KUHPerdata. Sehingga suatu perjanjian tersebut akan dinilai sah secara berdasarkan hukum yang ada pada transaksi elektronik yang telah dilakukan. Alat bukti hukum yang sah terdiri dari hasil cetak, dokumen elektronik, dan informasi elektronik seperti yang diatur dalam Pasal 5 ayat (I) UU ITE. Alat tersebut harus memenuhi persyaratan formil dan persyaratan materiil yang diatur dalam Undang-Undang lnformasi dan Transaksi Elektronik (UU ITE). Informasi elektronik terdiri dari suara, tulisan, gambar, dan foto yang merupakan jenis data elektronik seperti dalam ketentuan umum UU ITE. Terdapat berbagai jenis bukti elektronik, yaitu

a) Alat bukti yang sah terdiri dari hasil cetak suatu Dokumen Elektronik dan Informasi Elektronik yang diperoleh.

b) Sedangkan hasil cetak suatu Dokumen Elektronik dan Informasi Elektronik yang tercantum dalam ayat (I) adalah perluasan dari alat bukti yang sah berdasarkan Hukum Acara di Indonesia. (Pasal 5 Ayat I UU ITE).

Kegiatan transaksi elektronik yang berkaitan dengan arisan online, saat ini telah terdapat dalam UU No 19 Tahun 2016 yang merubah UU No 11 Tahun 2008 tentang ITE dan Pasal 378 KUHP yang mengatur tentang tindak pidana penipuan. Arisan online merupakan kegiatan transaksi elektronik yang dapat merugikan konsumen. Pelaku dapat diberikan sanksi meskipun UU JTE tidak memiliki aturan terperinci mengenai tindakan penipuan pidana. Sanksi yang diberikan berdasarkan ketentuan Pasal 28 ayat (I) dan Pasal 45A ayat (I) UU No 19 Tahun 2016, tentang perubahan atas UU No 11 Tahun 2008 tentang ITE. Serta tindak penggelapan dan penipuan pidana yang tercantum dalam Pasal 55 ayat (I) ke-le KUHP, Pasal 3, 4 UU No 8 Tahun 2010 tentang Pencegahan Tipikor, pasal 372 KUHP, dan Pasal 378 KUHP.

Pelaku penipuan online dapat diberikan sanksi untuk mempertanggungjawabkan perbuatan yang telah dilakukan berdasarkan U U No 19 Tahun 2016 tentang ITE, meskipun tidak secara khusus rnerniliki peraturan ketentuan tentang tindak pidana penipuan. Perbuatan melawan hukum yang dilakukan seseorang harus menerima pertanggungjawaban sesuai dengan tanggung jawab hukum 
yang terdapat pada hukum perdata. Jika dibandingkan dengan perbuatan pidana, ruang lingkup yang sangat luas dimiliki oleh perbuatan melawan hukum. Tindakan yang menentang hukum tidak saja berkaitan dengan tindakan yang memiliki hubungan dengan UU pidana, namun juga dapat bertentangan dengan UU lain bahkan dengan berbagai ketentuan hukum yang tidak tertulis. Pihak yang dirugikan dapat memperoleh perlindungan hukum dan memperoleh ganti rugi berdasarkan ketentuan perundang-undangan yang ada. Perjanjian yang menentukan hak dan kewajiban dapat melahirkan tanggungjawab perdata terhadap wanprestasi berdasarkan Kitab Undang-Undang Hukum Perdata. Sedangkan terdapat kaitan antara kewajiban dan hak yang memiliki sumber hukum dan mengatur tanggung jawab hukum perdata terhadap tindakan melawan hukum.

Berdasarkan uraian penjelasan di atas, terdapat cara menyelesaikan permasalahan yang timbul dalam menuntut hak dan kewajiban dalam perjanjian arisan. Bandar atau owner arisan merupakan pihak yang tergugat berdasarkan beberapa perkara yang ada. Hal ini terjadi karena peserta arisan tidak memperoleh dana arisan berdasarkan perjanjian yang telah disepakati. Pelanggaran ini terjadi karena adanya tindakan untuk tidak memenuhi kewajiban sehingga telah dilakukan wanprestasi atau perbuatan ingkar janji. Seorang bandar atau owner arisan dijatuhi hukum bersalah berdasarkan semua perkara yang membahas arisan online. Tidak dapat menyamaratakan setiap kasus yang yang menimpa arisan online karena pengurus atau bandar arisan memiliki tanggung jawab dan tugas berbeda. Hal ini terjadi karena terdapat perbedaan antara satu dengan yang lain mengenai praktik dan kebiasaan arisan. Dalam proses transaksi, terdapat pihak yang dirugikan atas tindakan wanprestasi. Terdapat beberapa jenis wanprestasi dalam KUHP yaitu seseorang yang tidak melaksanakan kewajibannya berdasarkan perjanjian yang tel ah dilakukan dan memiliki keabsahan secara hukum dalamjangka waktu tertentu sesuai dengan ketentuan yang telah disepakati secara bersama-sama oleh berbagai pihak.

Permasalahan di atas tidak dapat ditangani lagi oleh lembaga peradilan jika sebuah sengketa terjadi karena klausul alternatif atau perjanjian arbitrase, karena sudah tidak memiliki wewenang. Dalam menyelesaikan permasalahan perdata, kedua belah pihak dianjurkan untuk bermusyawarah sesuai dengan nilai yang terdapat dalam pancasila. Hal ini sesuai dengan petunjuk yang diberikan oleh UU untuk menyelesaikan permasalahan di luar pengadilan atau non litigasi. Bagi kedua belah pihak, terdapat alternatif penyelesaian yang dapat digunakan, yaitu metode mediasi dan negosiasi terhadap tindakan wanprestasi. Namun keputusan atau penyelesaian kasus yang diperoleh tidak mengikat kedua belah pihak berdasarkan praktek mediasi atau negosiasi. Dengan demikian salah satu pihak berhak menolak isi putusan karena tidak ada kewajiban untuk mematuhi isi dari keputusan yang dihasilkan.

Pihak yang dirugikan dapat menggunakan jalur litigasi melalui pengadilan untuk menggugat tindakan wanprestasi dalam perjanjian arisan online. Hal ini terjadi karena salah saru pihak merasa dirugikan karena tidak menemukan solusi atau penyelesaian masalah melalui upaya alternatif tersebut. Proses non-Iitigasi layak didahulukan jika kedua belah pihak yang bersengketa memiliki niat baik menyelesaikan kasus ten tang wanprestasi perjanjian arisan online .

\section{SIMPULAN DAN SARAN \\ 1. Simpulan}

Meskipun terdapat aturan bahwa perjanjian tidak hams dalam bentuk tertulis dalam ketentuan Pasal 1320 KUHP sebagai bentuk perlindungan hukurn arisan yang diselenggarakan secara daring. Namun arisan daring tersebut harus merniliki perjanjian dengan bentuk tertulis memang sangat diperlukan sebagai bentuk perlindungan jika terjadi wanprestasi.

Sanksi Pidana Terhadap Pelaku terdapat dalam UU No 19 Tahun 2016 tentang ITE tidak secara khusus mengatur kerentuan mengenai tindak pidana penipuan tetapi Undang-Undang tersebut tetap dapat diterapkan untuk memberikan sanksi pada pelaku yang melaksanakan tindak pidana penipuan online dan mempertanggujawabkan perbuatannya. Pasal 28 ayat (l) dan Pasal 45 A ayat (l) UU No 19 Tahun 2016 dapat dikenakan pada pelaku apabila timbul kerugian konsumen dengan transaksi dilakukan termasuk dalam kegiatan arisan online.

\section{Saran}

Di dunia maya terdapat banyak tindak penipuan akibat teknologi informasi yang berkembang pesat. Pemerintah belum sepenuhnya mengatur tentang fenomena tersebut sehingga mengalami kesulitan untuk menegakkan hukum pada kasus yang terjadi pada arisan daring. Tidak secara spesifik 
membahas tentang penipuan merupakan kelemahan dari Pasal 28 ayat 1 yang tercantum dalam UU ITE. Hal ini terjadi karena hanya dampak berita bohong yang ditujukan pada seseorang, yang memperoleh perlindungan hukum. Sehingga sesuatu yang terlibat dengan teknologi elektronik harus diatur dalam peraturan yang telah diterbitkan oleh Pemerintah, khususnya adalah tindakan penipuan daring.

Bagi masyarakat agar lebih berhati-hati dalam melakukan perjanjian, transaksi dan investasi (arisan online). Jika masyarakat mengalami peristiwa penipuan online, tidak terdapat sanksi tegas yang dapat diberikan pad a pelaku berdasarkan peraturan yang ada. Sehingga tindakan penipuan yang dilakukan secara daring sangat rnemburuhkan peran aktif pihak berwajib. Bagi pelaku atau pihakpihak arisan online agar kedepannya tidak mudah tergiur, tidak mudah percaya, dan tidak hati-hati dalarn melaksanakan transaksi dana secara daring. Pastikan anggota tersebut tidak merniliki masalah agar tidak mengalami kerugian ketika mengikuti arisan daring.

\section{DAFTAR PUSTAKA}

Ali, Achmad. (2002). Menguak Tahir Hukum. Toko Gunung Agung, Jakarta. Ali, Zainuddin. (2014). Metode Penelitian Hukum. Sinar Grafika, Jakarta

Fajar, Mukti \& Achmad, Y. (2015). Dualisme Penelitian Hukum (Normatif \& Empiris). Pustaka Pelajar. Yogyakarta.

Hariyanto, Hani., Noor Latifah and Syafiul Muzid. (2018). CMS Salmon: Digitalisasi Sistem Arisan Dan Lelang Motor Online', SNATIF, 5(1).

Khairandy, R. (2013). Hukum Kontrak Indonesia Dalam Perspektif Perbandingan. FH UII Press, Yogyakarta.

Kusuma, H. A. (1990). Hukum Perjanjian Adat. PT Citra Aditya Bakti, Bandung.

Mertokusumo, Sudikno. (2014). Mengenal Hukum Suatu Pengantar. Penerbit Liberty, Yogyakarta

Ramadhita \& Khoiriyah, I. R. (2018). Akad Arisan Online: Antara Tolong Menolong Dan Riba? Jurnal Hukum Islam Dan Pranata Sosial Islam, Vol. 8(1).

Riawan, B \& Mahartayasa, I. M. (2015). Perlindungan KonsumenDalam Kegia!En Transaksi Jua/ Beli Online di Indonesia. Jurnal OJS Unud, Vol 3(1).

Subekti, R. (2006). Aspek-Aspek Hukum. Perikatan Nasional, Bandung. 